\title{
UJI KELAYAKAN TANAH PADA PERENCANAAN SEPTIC TANK KOMUNAL DI LAHAN BERKONTUR PERMUKIMAN BANTARAN SUNGAI KOTA YOGYAKARTA
}

\author{
Hestin Mulyandari' dan Adwiyah Asyifa² \\ ${ }^{1}$ Program Studi Arsitektur Fakultas Sains dan Teknologi, Universitas Teknologi Yogyakarta \\ 2Program Studi Teknik Sipil Fakultas Sains dan Teknologi, Universitas Teknologi Yogyakarta \\ Email: hestin.mulyandari@uty.ac.id
}

\begin{abstract}
Code riverbanks are dominated by land for settlements, one of the points being the proposed establishment of rusunami, in Jetisharjo, city of Yogyakarta. Riverbanks at the location are slippery, so have many problems of structure and infrastructure. In the planning of rusunami, it is necessary to consider the location of the communal septic tank. The research use method of quantitative research. The results of soil testing are soil moisture content of $7.788 \%$, density of 2.688 , soil shear strength $(T)$ of $0.870 \mathrm{~kg} / \mathrm{cm} 2$, internal friction angle of $44^{\circ}$, and sandy soil. The results of the shear strength testing of the land that the selected location contain subgrade, so that if it will be used as a communal septictank, it needs to be made a strong enough foundation to avoid degradation and slope failure, the construction of communal septic tanks must be made strong so that they can avoid lift by water pressure.
\end{abstract}

Keywords: soil test, communal septic tank, contoured land

\begin{abstract}
ABSTRAK
Bantaran Sungai Code didominasi lahannya untuk permukiman, salah satu titiknya menjadi usulan berdirinya rusunami, di RW 07 Kecamatan Jetisharjo, Kota Yogyakarta. Bantaran Sungai di lokasi tersebut sangat curam, sehingga dari segi struktur dan infrastruktur banyak mengalami kendala. Pada perencanaan rusunami nantinya perlu diperhitungkan titik-titik yang menjadi lokasi septic tank komunalnya. Metode penelitian yang digunakan adalah penelitian kuantitatif. Hasil pengujian tanah sebagai berikut: kadar air tanah sebesar 7, 788\%, berat jenis sebesar 2,688, kuat geser tanah $(\mathrm{T})$ sebesar $0,870 \mathrm{~kg} / \mathrm{cm}^{2}$, sudut gesek internalnya $44^{\circ}$, dan berjenis tanah pasir. Dari hasil uji gesernya kekuatan tanahnya bahwa lokasi terpilih merupakan bekas tanah urug, sehingga apabila akan dijadikan septictank komunal perlu dibuatkan fondasi yang cukup kuat untuk menghindari penurunan dan kelongsoran tebing, maka konstruksi septic tank komunal harus dibuat kokoh sehingga dapat terhindar dari up lift oleh tekanan air.Disarankan menggunakan septic tank moderen (fabricated).
\end{abstract}

Kata kunci: uji tanah, septic tank komunal, lahan berkontur 


\section{PENDAHULUAN}

Kota Yogyakarta memiliki banyak sungai yang melewati beberapa daerah padat huni, salah satu diantaranya adalah Sungai Code. Daerah padat huni yang dilaluinya lengkap dari berbagai fungsi, yaitu permukiman, pendidikan, komersial, perdagangan, jasa, bahkan jalur transportasi.

Bantaran Sungai Code sendiri didominasi lahannya untuk permukiman. Beberapa titik di bantaran Sungai Code sudah menjadi usulan berdirinya rumah susun, salah satunya adalah di Bantaran Sungai Code di RW 07 Kecamatan Jetisharjo, Kota Yogyakarta. Warga di RW tersebut sudah setuju untuk didirikan Rumah Susun Milik (Rusunami), sehingga warga dengan status lahan Sertifikat Hak Milik (SHM) rencananya akan dibeli lahannya untuk dijadikan rusunami, dan warga berhak mendapatkan ruang tinggal di Rusunami tersebut.

Menurut Sapei (2011), semakin bertambahnya jumlah perumahan dan perkampungan yang mendiami satu area lingkungan, semakin berat pula lingkungan tersebut untuk menetralisir air limbah yang sebagian besar dihasilkan dari sisa penggunaan air bersih. Di Indonesia, air limbah pada umumnya langsung dibuang ke badan sungai tanpa dilakukan pengolahan (treatment) terlebih dahulu. Dikarenakan pelestarian sangat rendah, sehingga lingkungan sangat terganggu, dan mengganggu keseimbangan ekosistem. Akibatnya sungai yang berfungsi sebagai salah satu sumber air bersih, dapat membawa berbagai penyakit (vehicle) yang membahayakan kesehatan manusia, disertai dengan menurunnya kualitas lingkungan seperti penurunan kualitas air, tanah, dan udara, sehingga stabilitas lingkungan terganggu.

Bantaran Sungai Code di RW 07 Kecamatan Jetisharjo, Kota Yogyakarta, dengan gambaran lokasi sesuai gambar 1 sebagai berikut.

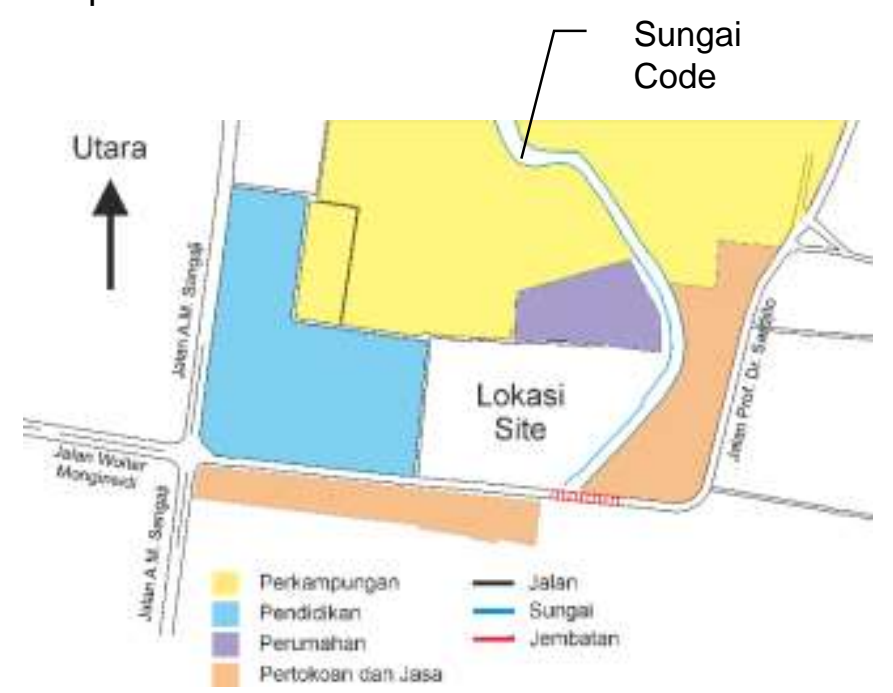

Gambar 1. Struktur Ruang Peruntukan Lahan Sekitar Site RW 07 Jetisharjo

Bantaran Sungai di lokasi tersebut sangat curam, sehingga dari segi struktur dan infrastruktur banyak mengalami kendala, antara lain adalah lokasi lahan tersebut berhimpitan dengan Sungai Code, pada kondisi eksisting permukiman tersebut sudah memiliki septic tank di tepian sungai yang letaknya menyebar dan belum tertata. Untuk itu pada perencanaan rusunami nantinya perlu diperhitungkan titik-titik yang menjadi lokasi septic tank komunal rusunami, sebelum ditentukan alternatif model septic tank komunal. Penentuan lokasinya untuk hunian vertikal akan diikuti dengan pengujian tanahnya, karena berkaitan dengan elevasi tanahnya yang sangat berkontur. Berikut perencanaan 
rusunami dan rencana perletakaan septic tank komunalnya pada gambar 2 .

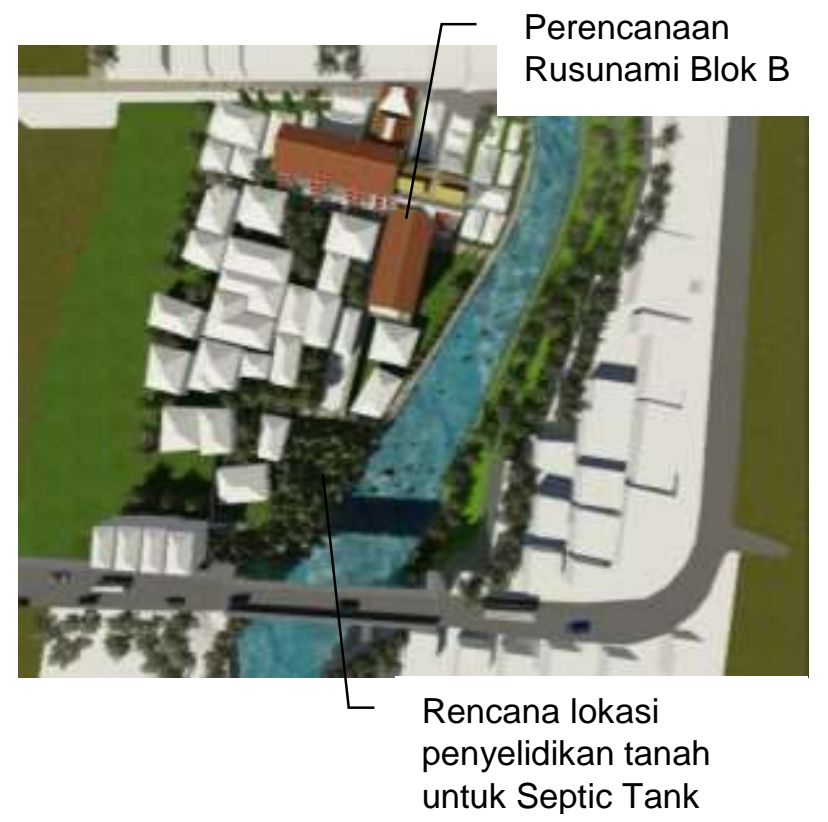

Gambar 2. Tampak Atas Kawasan pada Perencanaan Rusunami dan Rencana Perletakan Septic Tank Komunal
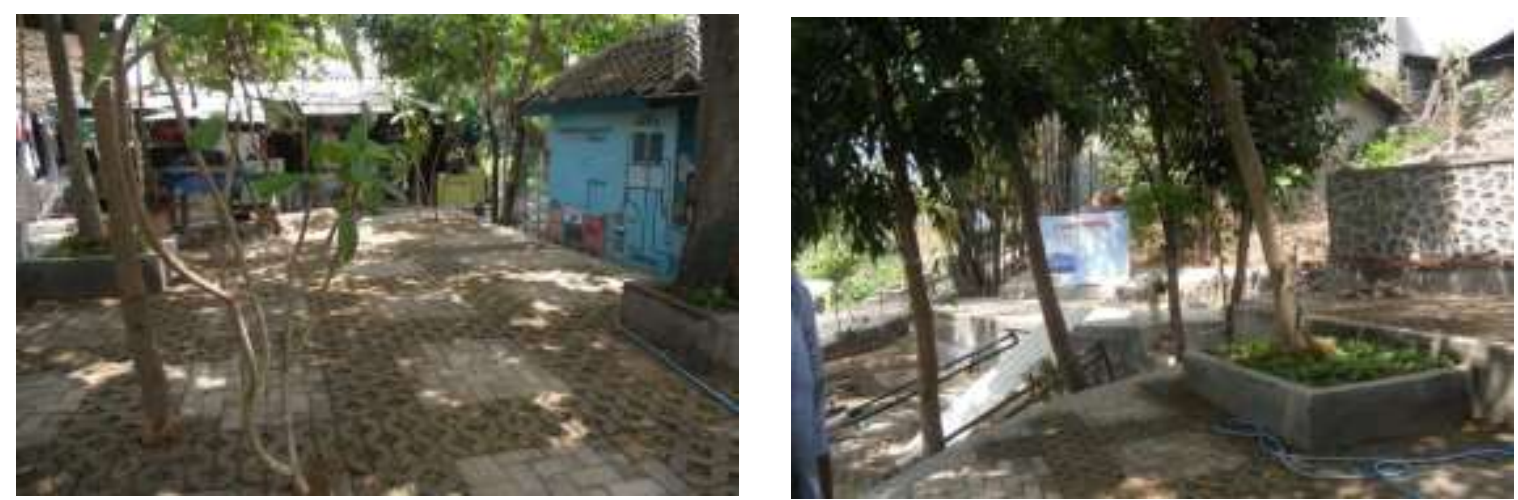

Gambar 3. Lokasi Penyelidikan Tanah

Lokasi penyelidikan tanah ditentukan pada taman terbuka (pada gambar 3) di sekitar bawah jembatan Sarjito, dikarenakan area yang lainnya pada kondisi eksisting lahannya penuh dengan permukiman warga. Penelitian ini bertujuan menghasilkan temuan kelayakan uji tanah untuk septick tank komunal pada lahan yang akan didirikan rusunami tersebut, agar yang tidak mencemari Sungai Code.

Menurut Soeparman (2002), sumber kontaminasi yang berupa tinja manusia yang ditempatkan dalam lubang dapat menembus permukaan air tanah, karena organisme coliform didapatkan pada jarak 4 sampai $6 \mathrm{~m}$ dari sumber kontaminasi. Kontaminasi tidak bergerak melawan arah aliran air tanah. Dengan kata lain, daerah kontaminasi tanah telah menyempit. Pola pencemaran secara kimiawi sama bentuknya dengan pencemaran bakteriologis, hanya jarak jangkaunya lebih jauh.

Mengacu pada Standar Nasional Indonesia (SNI) 03-2916-1992 tentang Spesifikasi Sumur Gali untuk Sumber Air Bersih baik sumur dangkal dan sumur dalam, bahwa jarak horizontal sumur ke arah hulu dari aliran air tanah atau sumber air kotor (berupa tangka sumur resapan/ tangki septic tank) lebih dari 11 meter, sedangkan jarak sumur untuk komunal terhadap perumahan adalah lebih dari 50 meter. 
Sedangkan jarak aman antara lubang kakus dengan sumber air minum menurut Chandra (2007: 162-127), dipengaruhi oleh berbagai faktor antara lain:

1. Topografi tanah : topografi tanah dipengaruhi oleh kondisi permukaan tanah dan sudut kemiringan tanah.

2. Faktor hidrologi : antara lain kecepatan aliran tanah dan kedalaman air tanah, Lapisan tanah yang berbatu dan berpasir. Diperlukan jarak yang lebih jauh pada lapisan jenis ini dibandingkan dengan jarak yang diperlukan untuk daerah yang lapisan tanahnya terbentuk dari tanah liat.

3. Faktor Meteorologi : di daerah yang curah hujannya tinggi, jarak sumur harus lebih jauh dari daerah sumur resapan atau septic tank.

4. Jenis mikroorganisme: bakteri patogen lebih tahan pada tanah basah dan lembab, begitu juga dengan cacing dapat bertahan pada tanah yang lembab dan basah selama 5 bulan, sedangkan pada tanah yang kering dapat bertahan selam 1 bulan.

5. Faktor Kebudayaan : seperti kebiasaan masyarakat di daerah tertentu yang membuat sumur tanpa dilengkapi dengan dinding sumur.

6. Frekuensi Pemompaan : semakin banyaknya air sumur yang diambil untuk keperluan orang banyak, laju aliran tanah menjadi lebih cepat untuk mengisi kekosongan.

Perencanaan septic tank komunal mengacu pada Lampiran Peraturan Menteri Negara Perumahan Rakyat Nomor: 04 Tahun 2011 Tentang Petunjuk Teknis Penggunaan Dana Alokasi Khusus Bidang Perumahan Dan Kawasan Permukiman, yaitu Persyaratan Kegiatan, pada point 10-13 sebagai berikut.

1. Persyaratan kegiatan diperlukan untuk mengetahui kesiapan/kemampuan sistem pembuangan eksisting untuk memenuhi kebutuhan pelayanan pembuangan air limbah rumah tangga bagi penduduk di lokasi perumahan baru.

2. Persyaratan Umum a. Tersedianya lahan yang cukup untuk membangun sistem pembuangan air limbah komunal di lokasi perumahan baru.

b. Penempatan septictank dapat ditempatkan pada lokasi yang telah direncanakan untuk septictank, atau pada lokasi ruang terbuka hijau (RTH), atau pada badan jalan, dengan memperhatikan kekuatan dan keamanan konstruksi.

c. Pelaksanaan pembangunan septictank dan sambungan pipa air limbah dari rumah-rumah, dilakukan secara terpadu dengan pelaksanaan pembangunan rumah dan kegiatan lainnya, sehingga sarana septictank tersebut bisa fungsional dan dapat dimanfaatkan oleh konsumen.

\section{Persyaratan Khusus}

a. Konstruksi fisik berupa septic tank komunal dengan kapasitas untuk melayani minimal 5 - $10 \mathrm{KK}$ dan maksimal $100 \mathrm{KK}$, dengan asumsi air limbah 10 liter/orang/hari.

b. Fungsi septic tank komunal hanya untuk pengolahan air limbah yang dibuang dari Water Closet (WC), tidak termasuk air limbah dari dapur dan kamar mandi.

c. Material septic tank harus kedap air. Untuk itu material yang bisa digunakan adalah sebagai berikut:

1) Pasangan batu bata dengan campuran spesi 1: 2 (semen: pasir).

Material ini sesuai untuk daerah dengan ketinggian air tanah yang tidak tinggi dan tanah yang relatif stabil sehingga saat pelaksanaan pembuatannya tidak sulit untuk menghasilkan konstruksi yang kedap air.

2) Beton bertulang. Material dari beton bertulang relatif sesuai untuk semua kondisi. Pada lokasi dengan muka air tanah tinggi bisa digunakan beton pracetak.

3) Plastik atau fiberglas. Material plastik atau fiberglass sangat baik dari segi karakteristik kedap airnya, namun rendah dalam kemampuan menahan tekanan 
samping tanah dan yang perlu diperhatikan adalah ketinggian muka air tanah yang yang bisa memberikan tekanan apung yang besar pada tangki jenis ini pada saat tangki kosong.

d. Pipa penyalur air limbah dari rumah menuju septic tank komunal harus kedap air, terbuat dari bahan PVC, keramik atau beton. Pemasangan pipa dengan kemiringan minimum $2 \%$, belokan lebih besar $45 \%$ dipasang clean out atau pengontrol pipa dan belokan 90\% sebaiknya dihindari atau dengan dua kali belokan atau memakai bak kontrol.

e. Septic tank dilengkapi dengan pipa aliran masuk dan ke luar. Pipa aliran masuk dan ke luar dapat berupa sambungan $\mathrm{T}$ atau sekat, pipa aliran ke luar harus $5-10 \mathrm{~cm}$ lebih rendah dari pipa aliran masuk.

f. Jarak septic tank dan bidang resapan ke bangunan $=1,5 \mathrm{~m}$, ke sumur air bersih = $11 \mathrm{~m}$ dan sumur resapan air hujan $5 \mathrm{~m}$. Tangki dengan bidang resapan lebih dari 1 jalur, perlu dilengkapi dengan kotak distribusi.

g. Perhitungan-perhitungan, kriteria, pemilihan jenis konstruksi dan material merujuk kepada standar perhitungan yang berlaku berdasarkan SNI-03-2398-2002 tentang Tata Cara Perencanaan Septictank dengan Sistem Resapan, serta pedoman tentang pengelolaan air limbah secara komunal sesuai dengan ketentuan peraturan perundang-undangan.

4. Ketentuan Lainnya

Agar pelaksanaan operasional dan pemeliharaan septictank komunal dapat berjalan lancar, maka perlu diatur mekanisme pembentukan pengelola septictank komunal berbasis masyarakat.

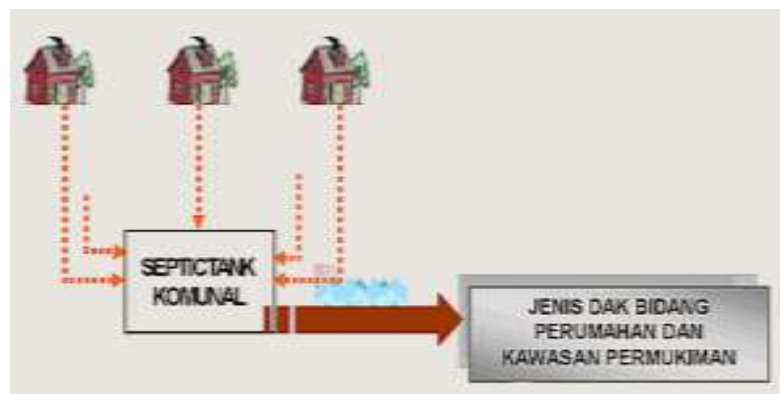

Gambar 4. Skema Septic Tank Komunal

(Sumber: Lampiran Peraturan Menteri Negara Perumahan Rakyat Nomor 04, 2011)

Skema Pelayanan Sistem Septic Tank Komunal Pada skema gambar no. 4, merupakan skema septic tank komunal minimal untuk 5-10 Kepala Keluarga (KK) dan maksimal untuk 100 KK. Pelayanan sistem septic tank komunal di perumahan baru yang akan didanai melalui dana alokasi Bidang Perumahan dan Kawasan Permukiman.

Temuan atau Inovasi yang ditargetkan berupa evaluasi dari analisa lahan di bantaran sungai yang ditinjau dari daya dukung tanah terhadap perencanaan penempatan infrastruktur septic tank komunalnya terhadap kesehatan lingkungan.
Salah satu yang paling krusial untuk bangunan di bantaran sungai, utamanya pada rusunami adalah permasalahan buangan air kotor, sebab bersinggungan langsung dengan sungai, sehingga apabila teknologi dan titik penempatan lokasinya tidak tepat akan membahayakan kesehatan penduduk setempat.

Dari segi ilmu penyehatan lingkungan, bangunan air limbah permukiman/ septic tank komunalnya yang akan direncanakan mengacu pada Buku Informasi "Melaksanakan Pekerjaan Bangunan Air Limbah Permukiman - Kementrian Pekerjaan - Badan Pembinaan Konstruksi - Pusat Pembinaan Kometensi dan Pelatihan Konstruksi tahun 2011. 
Beberapa ketentuan diantaranya, beberapa bangunan pengolahan air limbah yang digunakan pada system setempat diantaranya adalah:

1. Pengolahan air limbah dengan sistem setempat:
a. Tangki Septik
b. Filter anaerobic (bio filter)
c. Anaerobic baffled reactor

\section{METODE}

Penelitian ini menggunakan metode Penelitian kuantitatif yaitu suatu proses menemukan pengetahuan yang menggunakan data berupa angka sebagai alat menganalisis keterangan mengenai apa yang ingin diketahui (Kasiram, 2008: 149) dalam bukunya Metodologi Penelitian Kualitatif dan Kuantitatif). Uji kelayakan tanah di laboratorium tersebut diperlukan waktu selama 5 hari, untuk mendapatkan hasil terukur kuantitatif yaitu berupa: (1) grafik hubungan tegangan dan regangan; (2) grafik hubungan tegangan normal dan tegangan geser; (3) Indeks properties tanah. Pekerjaan penelitian dilakukan di lokasi perencanaan perletakan septic tank komunal yaitu di RW 7 Kecamatan

\section{d. Constructed wetland}

2. Pengolahan air limbah dengan sistem terpusat
a. Pengolahan pendahuluan
b. Pencacah
c. Parshall flume
d. Perangkap lemak/ grease trap
e. Bak perata/ equalisasi

Jetisharjo, Kota Yogyakarta, dengan mengambil sampel tanah yang ada di bantaran sungai dengan menggunakan peralatan hand bor. Sampel tanah tersebut kemudian di bawa ke laboratorium mekanika tanah Teknik Sipil Universitas Teknologi Yogyakarta. Analisis hasil penyelidikan tanah, apabila diketahui jenis tanah tidak memungkinkan untuk perencanaann septick tank, diperlukan penyelesaian masalah dengan beberapa alternatif konstruksi dan bahan septic tank komunal.

Sebagai gambaran proses penyelidikan tanah sebagai berikut.

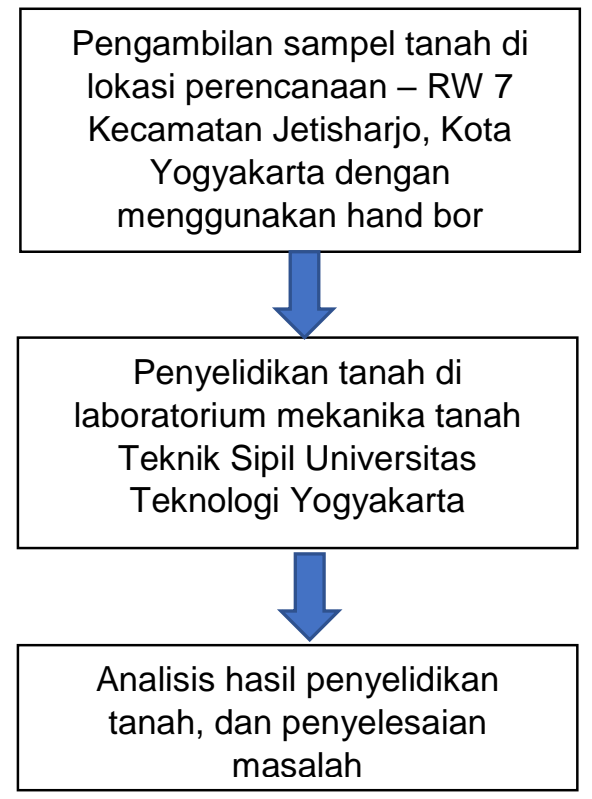

Gambar 5. Proses Penyelidikan Tanah 
Uji Kelayakan Tanah ... (Hestin/ hal 23-30)

\section{HASIL DAN PEMBAHASAN}

Berikut ini hasil uji penyelidikan tanah untuk pekerjaan kelayakan uji tanah untuk

pekerjaan septic tank komunal (Kali Code sisi utara Jembatan Sarjito).

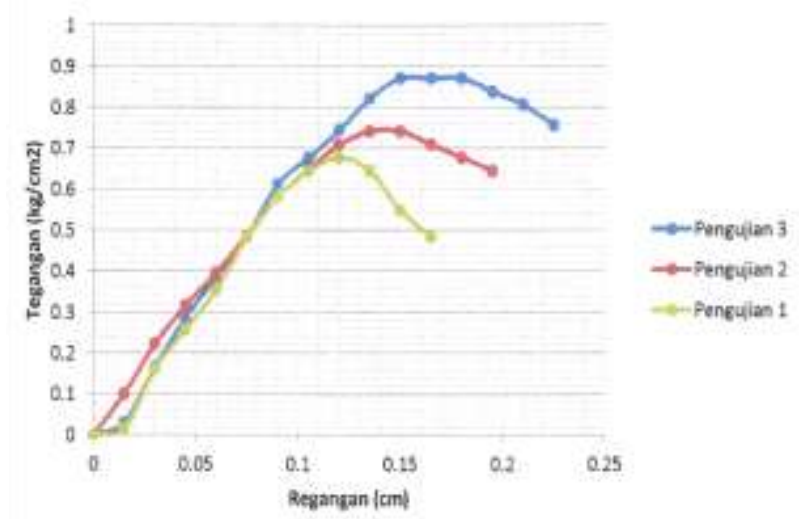

Gambar 6. Grafik Hubungan Tegangan dan Regangan

Pengujian geser langsung dilakukan dengan memberikan tiga variasi pembebanan yaitu $0,209 \mathrm{~kg} / \mathrm{cm}^{2}, \quad 0,417 \mathrm{~kg} / \mathrm{cm}^{2}$ dan 0,626 $\mathrm{kg} / \mathrm{cm}^{2}$. Pada pengujian 1 (beban 0,209 $\mathrm{kg} / \mathrm{cm}^{2}$ ) regangan didapatkan sebesar 0,12 $\mathrm{cm}$ dan tegangan geser maksimum 0,667.
Pengujian 2 (beban $0,417 \mathrm{~kg} / \mathrm{cm}^{2}$ ) regangan $0,15 \mathrm{~cm}$ dan tegangan geser maksimum $0,741 \mathrm{~kg} / \mathrm{cm}^{2}$. Pengujian 3 (beban 0,626 $\mathrm{kg} / \mathrm{cm}^{2}$ ) regangan maksimum $0,15 \mathrm{~cm}$ dan tegangan geser maksimum $0,870 \mathrm{~kg} / \mathrm{cm}^{2}$.

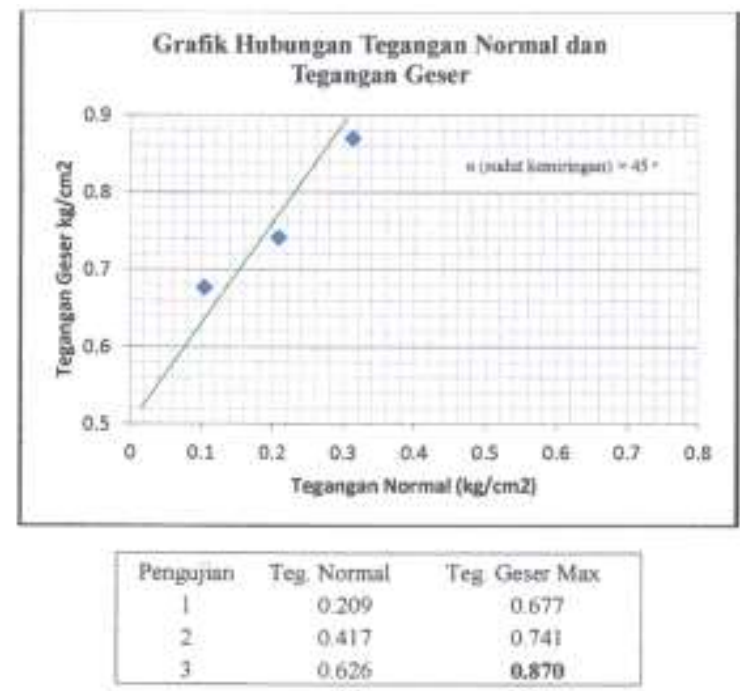

Gambar 7. Grafik Hubungan Tegangan Normal dan Tegangan Geser

Gambar 7, menjelaskan bahwa

Kuat geser tanah

$=$ Tegangan maksimum $\mathrm{X}$ tan $\alpha$

$=0.870 \times \tan 45^{\circ}$

$=0.870 \mathrm{~kg} / \mathrm{cm} 2$

Dari grafik hubungan tegangan normal dan tegangan geser maksimum, nilai sudut gesek dalam pada kondisi padat $(\Phi)=45^{\circ}$
Pengujian indeks properties tanah yang dapat dilakukan adalah batas susut tanah yaitu $20,44 \%$ baik terhadap perubahan volume maupun berat jenisnya.

Kesimpulan dari pengujian sampel tanah adalah sebagai berikut:
1. Kadar air tanah : $: 7,788 \%$
2. Berat Jenis $: 2,688$ 
3. Kuat Geser tanah $(\mathrm{T})$

: $0,870 \mathrm{~kg} / \mathrm{cm}^{2}$

4. Sudut gesek internal

$: 45^{\circ}$

5. Jenis tanah

: Pasir

Dari hasil uji gesernya kekuatan tanah tidak cukup besar kemungkinannya adalah bahwa lokasi yang dipilih merupakan bekas tanah urug, sehingga apabila akan dijadikan

\section{SIMPULAN}

Pada perencanaan rusunami di RW 07 Kecamatan Jetisharjo, Kota Yogyakarta perlu diperhitungkan titik-titik yang menjadi lokasi septic tank komunalnya. Metode penelitian yang digunakan adalah penelitian kuantitatif yaitu dengan analisis perhitungan pengujian geser langsung, hubungan tegangan dan regangan, hubungan tegangan normal dan tegangan geser, perhitungan pengujian berat jenis, perhitungan pengujian kadar air, dan perhitungan pengujian batas susut. Hasil pengujian tanah sebagai berikut: kadar air tanah sebesar $7,788 \%$, berat jenis sebesar

\section{DAFTAR RUJUKAN}

Badan Perencanaan dan Pembangunan Daerah Kota Yogyakarta. (2013). Laporan akhir Studi Pengembangan Kampung Wisata Kota Yogyakarta.

Anonim. 2011. Lampiran Peraturan Menteri Negara Perumahan Rakyat Nomor: 04 Tahun 2011 tentang Petunjuk Teknis Penggunaan Dana Alokasi Khusus Bidang Perumahan Dan Kawasan Permukiman.

Chandra, B. 2007. Pengantar Kesehatan Lingkungan. Jakarta: Penerbit Buku Kedokteran EGC.

Hardiyatmo, HC.2006.mekanika Tanah 1.Yogyakarta: UGM press.

Kasiram. 2008. Metodologi Penelitian Kualitatif dan Kuantitatif. Malang: Penerbit UIN Maliki Press, cetakan ke1.

Pratama, G. N. I. P., \& Sumarjo, H. (2018). Aksesibilitas Tata Letak Elevator Penumpang Gedung Kantor Pusat Layanan Terpadu (KPLT) Fakultas Teknik UNY. INformasi dan Ekspose septictank komunal perlu dibuatkan fondasi yang cukup kuat untuk menghindari penurunan dan kelongsoran tebing. Mengingat lokasinya di tepi sungai, maka konstruksi septic tank komunal harus dibuat kokoh sehingga dapat terhindar dari up lift oleh tekanan air. Sangat disarankan untuk menggunakan septink tank fabricated.

2,688, kuat geser tanah $(\tau)$ sebesar 0,870 $\mathrm{kg} / \mathrm{cm}^{2}$, sudut gesek internalnya $44^{\circ}$, dan berjenis tanah pasir. Dari hasil uji gesernya kekuatan tanahnya bahwa lokasi terpilih merupakan bekas tanah urug, sehingga apabila akan dijadikan septictank komunal perlu dibuatkan fondasi yang cukup kuat untuk menghindari penurunan dan kelongsoran tebing, maka konstruksi septic tank komunal harus dibuat kokoh sehingga dapat terhindar dari up lift oleh tekanan air. Disarankan untuk menggunakan septic tank moderen (fabricated).

hasil Riset Teknik Slpil dan Arsitektur, 14(1), 26-35.

Sapei, A., Purwanto, M.Y.J, Sutoyo, \& Kurniawan, A. (2011). Desain Instalasi Pengolah Limbah WC Komunal Masyarakat Pinggir Sungai Desa Lingkar Kampus. Jurnal IImu Pertanian Indonesia. Volume 16. No. 2 dan Halaman 91-99.

Soeparman dan Suparmin. 2002. Pembuangan Tinja \& Limbah Cair (Suatu Pengantar). Jakarta: Penerbit Buku Kedokteran EGC.

Standar Nasional Indonesia (SNI) 03-29161992 tentang Spesifikasi Sumur Gali untuk Sumber Air Bersih, 